\title{
Golden geese or white elephants? The paradoxes of world heritage sites and community-based tourism development in Agra, India
}

\author{
Surajit Chakravarty ${ }^{\mathrm{a}}$ and Clara Irazábal ${ }^{\mathrm{b}}$ \\ ${ }^{a}$ Department of Urban Planning, ALHOSN University, Abu Dhabi, UAE; ${ }^{b}$ Graduate School of \\ Architecture, Planning, and Preservation, Columbia University, New York, USA
}

\begin{abstract}
This study examines the relationship between World Heritage Sites (WHSs) and local community development in Agra, India. We investigate two interrelated themes: the role of planning in developing the tourism potential of the Taj Mahal and other WHSs in Agra, and the impact of the WHS framework on the development of the city. We analyze the weaknesses of the institutions and agencies responsible for Agra's inability to convert the development potential created by its three WHSs into significant economic, community and infrastructure improvements. The Agra case reveals a set of developmental paradoxes, whereby the restructuring of the tourist industry induced by the designation of WHSs does not lead to proportionate advances in local community development. Several factors were found to be systemic problems, but some recent schemes are worth supporting and expanding. The paradoxes and potential of economic, tourism, and community development in Agra echo those of other developing localities which host WHSs around the world. Following an assessment of problems and challenges, a set of recommendations is directed toward the development of pro-poor, community-based heritage tourism with the aim of informing integrated planning for the community and for heritage and tourism resources in the future.
\end{abstract}

Keywords: world heritage sites; community-based tourism; planning; Agra; India

\section{Introduction}

This study examines the relationship between World Heritage Sites (WHSs) and local community development where these sites are located, particularly in the context of small cities in the developing world. Our case study is the city of Agra in India, where three WHSs, including the renowned Taj Mahal, are located in close proximity to each other. We investigate two interrelated themes: the role of planning in developing the tourism potential of the Taj Mahal and the other WHSs, and the impact of WHS-related policies in the development of the city of Agra. This inquiry stems from the observation that the city of Agra has not converted the development potential created by the presence of three World Heritage designated sites into significant economic, community and infrastructure improvements. In its Final Report on 20 Years Perspective Plan of Uttar Pradesh, the state where Agra is located, the Department of Tourism, Government of India notes that "Agra has

*Corresponding author. Email: surajitc@usc.edu 
very poor civic conditions with dirty roads, lanes and drains" (2002, p. 3). Further, in profiling of the city, the National Institute of Urban Affairs (NIUA) reports that:

Agra is growing rapidly and lacks the infrastructure to cope with its rapidly increasing population... Agra faces a remarkable number of challenges in water, sewerage, municipal finance and administration. The municipal solid waste system, for example, is unable to cope with some 650 tons of garbage generated daily, more than a third of which lies uncollected in the streets. (NIUA, 2001)

The Agra case study reveals a set of developmental paradoxes whereby a city is unable to convert World Heritage designation into proportionate advances in local community development in a context where it is sorely needed. It is therefore legitimate to ask whether, in the context of developing cities, WHSs are "golden geese" or "white elephants"-i.e. are they catalysts for community development or added burdens on local infrastructure and budgets?

Several institutional and planning variables were found to be systemic problems in the quest for socio-economic development in Agra, including dearth of funds, the overlapping and indistinct agendas of various agencies, a lack of cross-sectoral coordination, conflicting interests and motives of stakeholders, and the lack of a propoor, community-based heritage tourism vision. Our recommendations include change in the organizational structure of tourism management, spatial innovation, and increased community involvement.

\section{Effects of World Heritage designation on community-based tourism development}

2010 marked the 40th anniversary of the signing of the United Nations Educational Social and Cultural Organization (UNESCO) World Heritage Convention, which launched the concept of "world heritage" and began the process of listing sites deemed to possess "outstanding universal value." WHSs are some of the most recognized locations around the world. They are irreplaceable, usually government-owned, have iconic status related to national identity, and are significant contributors to the tourism industry. In addition, conservation and tourism development in and around significant heritage sites often involves a large number of stakeholders. Issues such as WHS designation, interpretation, marketing, visitor management, and revenue generation are often complex and controversial. The responsibility of managing them appropriately and ensuring that resources are not damaged by visitors, conflicts of interest, or environmental conditions is therefore vital.

Cultural heritage planning and management is a global phenomenon governed by a series of internationally recognized codes and charters (including the Venice Charter, 1994, and the UNESCO World Heritage Convention, 1970). These transnational agreements systematically advocate that responsible parties "maintain the cultural values of cultural heritage assets for the enjoyment of present and future generations" (McKercher \& du Cros, 2002, p. 43). The purpose of this is to conserve a representative sample of cultural heritage worldwide, and to interpret its intrinsic value for widening public appreciation. This is done for both tangible (physical evidence of culture, e.g., the built environment) and intangible (continuing cultural practices, knowledge, and living experiences) heritage on varying scales and with varying complexity (Bowen, 2004; McKercher \& du Cros, 2002). 
But clearly this agenda is not having the intended results or benefits in Agra, where three sites have been designated WHSs: existing conditions there, with respect to infrastructure provision, the quality of the tourist experience, and the financial benefits being drawn from heritage sites, are far behind and woefully disproportionate to the city's - and its sites'-potential. This presents a fundamental developmental paradox, whereby valuable cultural resources such as WHSs can become burdens in two compounded ways: on the one hand, by exerting costs in terms of restoration, maintenance, and policing expenses associated with the preservation and management of the monuments and the impact that tourists have on quality of life, in terms of use of services and infrastructure; and on the other, by exacerbating inequalities among the city's residents, and among city residents and people at other scalar points (state, nation, and globe), depending on the inequitable distribution of opportunities, costs, and benefits of tourism development associated with the WHSs.

\section{Notes on methodology}

We are in agreement with Shanks (2009) that in tourism studies, “[t]he industry's elasticity means that quantitative projections are less helpful in understanding what politics is, and for identifying prospective winners and losers, than are qualitative sketches outlining how power relationships are elided in different spheres." Schyvens (2007, p. 132) also suggests that "rather than focusing too much on tourism's 'impacts' we need detailed studies of systems, processes, places and interactions between people, in order to understand how culture and power influence the actions of tourism stakeholders." Thus, our analytical framework includes exploring the motives, powers, and interrelationships of the various stakeholders; a critical examination of plans and policy outputs; interviews with key informants in government, para-statal, and NGO sectors; and on-site reconnaissance, photographic surveys, and informal interviews.

Research material was collected using a variety of methods, including a review of theoretical literature related to heritage tourism planning and management as well as official charts, mandates, proposed and accepted plans, and regulations pertinent to the case study. For additional information we conducted semi-structured interviews with representatives of various relevant agencies, including the Agra Development Authority (the principal planning agency), the Archaeological Survey of India (in charge of managing heritage sites), the Center for Urban and Regional Excellence (an NGO working on community-based projects in Agra), the Indo-USAID Financial Institutions Reform and Expansion Project (agency supporting governance reforms and community-based solutions), and the National Institute for Urban Affairs (a para-statal organization advocating municipal reforms). These interviews were carried out between May 2008 and August 2009. Finally, our own observations regarding land use, urban design, and transportation in the study area, as well as informal interviews of site residents and visitors, complement the other findings.

\section{The management and planning of heritage tourism in Agra}

\section{(i) Agra and its world heritage sites}

Located on the banks of the river Yamuna, Agra city lies within Agra District (the equivalent unit to "county" or "borough" in the US context), which falls within the 
State of Uttar Pradesh (UP). The city is 202 kilometers from India's capital, New Delhi, and 378 kilometers from Lucknow, Uttar Pradesh's capital. The city was founded by Sikandar Lodhi to be the capital of the Lodhi dynasty. Sikandar Lodhi's son Ibrahim was defeated by Babur in 1526, and the Mughal dynasty was established in India. It was Babur's great-great-grandson Shah Jahan who built the Taj Mahal between 1632 and 1653 .

The city is famous as the site of one of the most sought-after tourist experiences in the world - the Taj Mahal, but also includes two other important sites: Agra Fort and Fatehpur Sikri. The Fort was constructed under the Emperor Akbar (grandson of Babur) in 1565. "This bastionned fortress, with walls of red sandstone rising above a mat, encompasses within its enclosure walls of 2.5 kilometers, the imperial city of the Mogul rulers" (UNESCO, 1983). Both the Taj Mahal and the Agra Fort were inscribed as UNESCO World Heritage sites in 1983. There is yet another WHS in the Agra District, Fatehpur Sikri, only 40 kilometers from Agra City. Fatehpur Sikri was built as a large palace and city by Akbar in 1571, and was used as the capital until it was abandoned in favor of Agra Fort in 1585. It was instated as a UNESCO World Heritage site in 1986.

The iconic position and marketing of the Taj Mahal as India's "brand ambassador" (Khosla, 2009, recorded interview) and "the ultimate symbol of love" cannot be overstated. The Taj is the centerpiece of the "Incredible India" campaign launched recently by the Ministry of Tourism, where it is described as "the most photographed monument in the world." A 2001 study by the Agra Development Authority reported that the monument attracted 2.25 million visitors annually, of whom about $11 \%$ were foreigners. According to the Ministry of Tourism, by 2005 that number rose to 2.48 million, $24 \%$ of whom were foreigners.

The Taj Mahal is globally recognized and appreciated as a symbol of India. Most foreign dignitaries visit the monument, with the press sending pictures around the world. In the early 1980s, reports of damage to the white marble surface of the monument from air pollution drew concern from diverse groups (including research organizations, private corporations, and the UN), showing both a sense of respect and of ownership of the monument beyond national boundaries. This resulted in prompt action from the responsible agencies to institute pollution control measures in the vicinity of the structure and appropriate restoration funds to polish the marble surfaces. Since it is so much in the public eye and part of the branding of the country itself, a well-managed Taj would presents an image of efficient governance. On the other hand, mismanagement suggests weak institutions and a lack of accountability.

The Taj's potential for attracting tourists has not, however, been translated into significant tourist spending that benefits community development. One reason is the lack of integration with other tourist sites in the city. Although Agra was an important center in India's first (ultimately unsuccessful) struggle against British rule in 1857, the city's history is inadequately highlighted in the tourist experience. There is also a lack of promotion of its other two World Heritage sites. Information regarding these sites appears in most tourist guidebooks, but the Taj so overshadows everything else in Agra that few people even know the name of the city before they begin to make their travel plans. This translates to the Taj being perceived as the only important site to be seen there, even though Agra is also home to Itmad'ud Daulah, Akbar's tomb, Ram Bagh, Jama Masjid, Chini ka rauza, Mariam's tomb, and Guru ka tal, among other sites. Although these places are not all designated as World Heritage Sites, they have great historic and cultural significance in India. 
Another problem is that although the Taj Mahal draws tourists from around the world, it only holds them for a couple of hours. Once it has been admired from all angles, and digital cameras have been filled up, tourists move on. Some will visit the other two World Heritage sites. For most, Agra will still remain a city that can be "covered" in one day. It is common for tourists not to stay overnight in Agra, preferring instead to make a day trip from Delhi, or to stay just one night in order to have a "thorough" experience.

Edensor's (1998) authoritative work on the tourist experience of the Taj Mahal is a rich source of information about the local tourist industry gathered from stakeholder groups on both the demand and supply sides. Edensor reports voices of business owners, tour guides, and the local unemployed, among many others. Studying these narratives uncovers the monument's many meanings. Some of the main themes to emerge are the significance of the Taj in popular consciousness; foreign tourists' disappointment with the quality of the experience beyond the structure itself; and the sheer complexity of the management of the site, considering the diversity of government agencies, political motives, and social needs. Edensor's critique is supported by our fieldwork; however, he offers little in terms of ideas about what to do about it. We get commentary on various issues (e.g., the theming of tourism), but not a critical examination of the issues themselves.

\section{(ii) Agencies with planning and management roles}

In order for a site to be designated as a WHS, proponents - usually a combination of environmental or cultural preservationist groups and local and national governments - need to comply with a series of requirements that document the site and its importance, and also offer specific proposals and commitments to plan and manage it. This process of "getting an act together" for the purpose of achieving a favorable evaluation on the part of the UNESCO Committee can result in a positive boost for planning, management, and development of the site and its surroundings. For instance, a condition of designation as a World Cultural Heritage Site is the adoption of a zoning plan and legal framework for protection and management. Such a zoning plan focuses on promoting sustainable development of heritage resources in harmony with the natural and social fabric of the site. It attempts to achieve a balance between protection of heritage sites, planned development of tourism, and urban or rural development. The pertinent government is expected to establish agencies to manage the site and regulate development (Wager, 1995).

Harrison and Hitchcock's (2005) study of WHS management from around the world points out an underlying tension between global strategies for attaching meaning to heritage and managing it, and local particularities represented by the needs and expectations of communities at given places and times. According to Gregory Ashworth, there are "inherent logical contradictions, intrinsic inconsistencies, unsatisfactory procedural compromises, and unresolved policy dilemmas that surround the idea and practice of world heritage" (Ashworth, 2006, p. 274; Drost, 1996; Harrison \& Hitchcock, 2005). This may be because in many localities there is a "gap between ideal conservation management and the reality of urban development trends and tourism activities" (Shetawy, 2009, p. 1).

Although both tourism and world heritage designation have been studied at length, there is relatively less research on WHSs in the context of cities in developing countries. Nuryanyti (1996) describes how cities in developing countries often have 
to deal with the challenge of having a WHS "in the middle of living communities" ( $p$. 256), often with large and dense populations, more pressure on infrastructure, and the tendency for development of any kind to be treated as a sectarian political project. They face the added challenges of limited funding resources and inadequate institutional capabilities (p. 257). Under these conditions, substantive and sustainable community development often takes a back seat to personal agendas, and participation becomes knee-jerk rather than constructive and proactive. Thus, achieving sustainable and equitable community-based tourism development (CBTD) in developing countries faces serious challenges related to tourism management and power dynamics (Ryan, 2002). These challenges and some basic actions to tackle them were clearly stated by Brohman (1996, p. 48):

The Third World $[s i c]$ tourism industry has grown rapidly, but has also encountered many problems ... including: excessive foreign dependency, the creation of separate enclaves, the reinforcement of socioeconomic and spatial inequalities, environmental destruction, and rising cultural alienation. To avoid such problems, institutional mechanisms need to be created to encourage active state and community participation in tourism planning.

Thus it is important to examine the functioning of local agencies responsible for WHS management in Agra. Planning and development of the WHSs and tourism there fall under the jurisdiction of various government agencies at various scales. In this section we analyze the relationships and plans of these various agencies and highlight some of their weaknesses. We also discuss the role of another agency, the Taj Expressway Authority.

\section{Archaeological Survey of India (ASI)}

The Archaeological Survey of India works under the Ministry of Culture in India's central government. ASI's mandate includes archaeological research, preservation of protected monuments and areas of national importance, maintenance of site museums, and overall regulation of legislations related to antiquities and art treasures (ASI, 2008). ASI handles the management of historic structures and the immediate enclosures around them: the upkeep and maintenance of all aspects of the area inside the entry gates, including cleanliness, protection from environmental damage, and architectural restoration. Recent restoration work at the Taj Mahal has included filling-in missing inlay work, mudpack treatment for restoring marble luster, structural work, and the renovation of broken pedestrian paths. As a representative of ASI told us in an interview, the agency has no direct collaboration with other agencies involved beyond giving comments to ensure conformance with aesthetic guidelines.

ASI is also the agency that proposes sites to the United Nations for qualification as WHSs. It is responsible for liaising with the UN and ensuring that the proposed sites meet the parameters and guidelines associated with World Heritage designation. Assigning these tasks to ASI shows that the national government wants to keep this process within its own purview. The central government does not, however, attach a similar level of importance to the management of the urban contexts within which the structures are located. This shows that while the cultural significance of the WHSs is understood, their potential as income-generators and community development instruments has not been given proper attention at the national level. 


\section{Other national actors}

In the case of the Taj Mahal, the Indian Administrative Service (IAS) has formed the Taj Monitoring Committee, which is a working group that brings together officers from the various districts around Agra. The Supreme Court also has its own focus group working solely on the Taj Mahal, scrutinizing every proposed development that may affect it. These agencies work primarily to preserve the Taj from the prospect of damage due to hasty or unplanned development.

\section{Uttar Pradesh Tourism}

At almost 200 million inhabitants, Uttar Pradesh (UP) is the most populous state of India; it is also home to many sites of religious and architectural significance. Tourism in India is fairly decentralized; state governments have the mandate to develop tourism programs and infrastructure in their jurisdictions. UP Tourism's planning is largely non-spatial. The department makes programs, issues licenses (to hotels, tour operators, guides, etc.), and does publicity work. The department also does some construction work, limited to properties operated by it, such as guest houses, parks, etc. UP Tourism has no influence on the planning and development of Agra city. Indeed, spatial planning and community development in Agra is not viewed as intrinsically related to the planning and development of tourism.

\section{Agra Nagar Nigam (Agra Municipal Corporation)}

The Municipal Corporation is responsible for various functions at the city level. These are mostly related to urban infrastructure and services (street lighting, road maintenance and cleaning, water supply, waste collection, etc.). The Municipal Corporation has no construction or urban planning role, and its involvement in planning for tourism is minimal. Even so, road cleaning and maintenance, a responsibility of the Municipal Corporation, is one of the main problems around the WHSs. Roads leading up to the monuments are in poor repair and have minimal traffic management. In Agra, where image and marketability are paramount and resources are few, an innovative approach to managing access to heritage monuments is necessary.

\section{Agra Development Authority (ADA)}

The Authority was established in 1975 to handle housing and carry out the planned development of the city. Its scope of work includes the preparation of the Agra Master Plan, approving building and site plans, controlling and regulating development according to land use plans, road construction, drainage, and construction and maintenance of parks and recreation facilities. This profile of activities makes ADA the primary agency responsible for the physical development of the city, including the area around the heritage sites.

The ADA Master Plan for 2021, approved in 2001, lists 45 sites in and around Agra protected by ASI. As indicated, three of these are WHSs. The plan has a special section on tourism, which proposes a Taj Heritage Zone. Provisions include the relocation of industrial units from inside to outside the zone; a ban on construction within 500 meters of the Taj grounds and 100 meters of other monuments; and a height limit of 3.75 meters (that is, one floor only) within 100-300 meters of 
protected monuments. A Mughal-style façade is required on all proposed buildings in the zone. The plan also includes land reclamation from the Yamuna River behind the Taj Mahal for creating a park and a dam downstream from the Taj to allow high water levels to be maintained year round near the monument, thereby encouraging boating and views from the water. Sewage disposal in the river will be diverted to a downstream location to keep the river water clean in the tourist area. Finally, pedestrian paths and street improvements will create better access to the monuments. The new zone has in fact been created, and some improvements are underway.

The Master Plan is generally well thought-out and helpful (except for the river reclamation and sewage disposal plans, which need a more thorough environmental approach). However, it reflects the constraints of resources, political will, and popular opinion. In addition, to some extent it displays the classic flaws of rationalist planning-lack of public involvement and a top-down approach with very little flexibility. And it has a limited physical-planning approach and spatial scale (relative to the actual area it is likely to influence). Tourism planning is limited to a small area around the Taj Mahal, most of which comprises parks, river, and the existing old city. There is no proposal, for example, to spatially integrate multiple major landmarks and monuments, or to institute year-round programming, or to incorporate parts of the old city. The limitations of the plan are partially the result of a technocratic and bureaucratic planning system that has made every agency responsible for isolated functions with no incentives to cooperate or innovate.

\section{Taj Expressway Authority (TEA)}

This large-scale project was abandoned due to sectarian politicking. The Taj Expressway Plan, which proposed the connection of Agra and Delhi by a new expressway, would have cut the driving time from 5 to 3 hours. TEA, which was created to plan development along the corridor (an 8-lane highway), proposed Special Development Zones (SDZs) along the expressway corridor to be developed using private capital. Core activities proposed for SDZs included information technology, bio-tech and other industries, recreation, and entertainment retail, although $15 \%$ of the land was reserved for residential use. The thinking behind the plan was that tourists who were staying in Agra for a very short time, could be enticed to stay longer if the area had entertainment-retail complexes-under the apparent presumption that the areas three WHSs were not enough.

\section{Summary: lack of efficient institutional structure and clear mandate}

Planning for a city in Agra's position must involve job creation and training, private sector incentives for development, and transportation and urban design improvements as its core elements. However, as the breakdown of responsibilities above demonstrates, the presence of too many agencies and stakeholders with overlapping goals and approaches makes such an integrated effort challenging.

In India, city development is the responsibilities of local authorities. This policy works fine in large cities such as Delhi and Mumbai, which have greater technical capacity and financial resources. But in a relatively less-endowed context like Agra's, local authorities usually have deficient technical, financial, and/or managerial capacity. Municipal authorities and development corporations, the two local bodies 
responsible for urban infrastructure and development, can barely maintain day-today operations within their limited budgets.

At present, there is no single authority or coalition that is responsible for creating and executing a comprehensive vision for realizing the full potential of the Taj Mahal and the other WHSs. Tensions between global institutions, national image-making projects, and local planning needs are embedded in planning processes, and each set of agents operates with independent agendas and little regard for the others. Mr. Chetan Vaidya (2008), Director of the National Institute of Urban Affairs (NIUA), explained the situation in an interview: "the national government does economic planning with little regard for the spatial aspects, and at the local level spatial planning ignores economic aspects."

In addition, political success or failure at the city level has only a small, usually insignificant effect of the outcome of national elections. The state government, on the other hand, could make political gains by pursuing local community development, but lacks the vision for change. The municipality has no organizational, technical, or financial capacity to make big plans. The present arrangement of agencies and their lack of cross-sectoral coordination are, in part, responsible for the community development potential of the WHSs not being fully realized.

Aside from the multitude of Indian agencies already discussed, UNESCO is also a powerful stakeholder, as the maintenance of World Heritage designation is contingent upon its approval of plans in and around the sites. But like local and state agencies, UNESCO World Heritage Committee historically has restricted its purview to its direct mandate: preservation of the monuments and the environmental issues that may threaten them, with scant, if any, attention granted to community development issues. Likewise, the ASI, a powerful lobby, is interested in no more than its jurisdiction - which is the monuments and the parks and facilities inside their walled compounds. Meanwhile, the array of stakeholders involved has limited direct engagement in development plans.

\section{Assessment of tourism development in Agra \\ Lack of holistic planning}

There is a need to plan a more comprehensive heritage tourist experience tapping into the multifaceted assets of Agra. Cultural heritage tourism worldwide has gone from a small niche market to be "firmly established as a mainstream, mass tourism activity" (McKercher \& du Cros, 2002, p. 135), and so should be leveraged for maximum benefit. Cultural heritage planning and management ought to incorporate tourism into plans both for providing for tourists and the locals, and for protecting heritage assets (McKercher \& du Cros, 2002). Yet, as Bowen (2004, p. 409) suggests,

While tourism professionals assess cultural assets for their profit potential, cultural heritage professionals judge the same assets for their intrinsic value. Sustainable cultural tourism can only occur when the two sides form a true partnership based on understanding and appreciation of each other's merits.

Relationships between heritage tourism and local people involve more than jobs and wages. They include questions of land ownership and property rights, competition between the old and the new, changing lifestyles, questions such as what to preserve for whom/what purpose, and the interaction between tourists and host communities 
whose different socio-cultural structures and expectations can lead to misunderstandings and conflicts (Nuryanti, 1996).

In this framework, community development opportunities abound: locals can be trained and employed for the creation, maintenance, and improvement of the tourist infrastructure and services; ADA could design and execute a plan to create an integrated multi-destination circuit along major well-maintained thoroughfares; tourists should be encouraged to get the full experience of the destination by touring all its small sites; options for consumption, entertainment, and even worship could be offered; and the promotion of some sections of the neighborhoods around the Taj as living cultural quarters could be considered. A religious/spiritual center/museum could be created to complement and interpret the state's tourism offerings, which include many spiritual destinations. The objective of these interventions would be to tie together the region's major heritage tourism attractions with its everyday cultural offerings.

\section{Lack of basic infrastructure and funds}

Due mostly to a chronic lack of funds, Agra's poor level of physical infrastructure makes it hard to sell as a destination city. The streets are congested and broken, the traffic is chaotic, traffic lights do not work, public transport is only basic, and hotels and other tourist infrastructure and services are minimal. Social infrastructure to improve health, education, and tourism-oriented job training are also lacking. It falls to the government at the city and state levels to rectify these problems through investments, incentives, and regulations.

\section{Stunted private involvement}

Heritage tourist development as a planning strategy requires the organization of land use so as to strategically take advantage of the proximity of monuments. This land is best suited for parks, promenades, museums, pedestrian-only shopping multipurpose streets, etc. Some of these uses require private sector investment. The government, however, must zone for and encourage such development through tax breaks, subsidies, public-private partnerships, and small entrepreneurial opportunities such as microfinance and industry incubators.

Currently, there is surprisingly little innovation in Agra. To some extent the responsibility lies with the government's lack of planning for private sector opportunities. For example, when the Taj Expressway Plan finally attempted to attract investment, its plan did not fit the profile of strengths and weaknesses of Agra. Authorities should have realized that visitors could not be enticed to stay in Agra in order to do something they could easily do in Delhi, such as shopping at malls. The Expressway was, however, an attempt to try something new at a regional scale, an idea that should be revisited.

\section{The way forward: rethinking governance, community and space}

Ashley and Roe (2001, p. viii) have proposed pro-poor tourism (PPT) strategies, which "aim to increase the net benefits for the poor from tourism, and ensure that tourism growth contributes to poverty reduction. PPT strategies aim to unlock opportunities for the poor - whether for economic gain, other livelihood benefits, or 
participation in decision-making" (see also Harrison \& Schipani, 2007; Kakwani \& Pernia, 2000).

Responsibility for cultural heritage management has gradually been transferred from the non-profit public sector to the for-profit, private sector. Although this has created new challenges, it has also opened new models of cultural heritage management and the tourism industry, a continuum "from full partnership cooperation, through parallel existence and blissful ignorance, to full and open conflict." The result of each side continuing to ignore, misunderstand, or fight the other is "the suboptimal delivery of cultural tourism products and then continued unsustainable development of this sector" (Bowen, 2004; McKercher \& du Cros, 2002, p. 23). In addition to striking a fruitful balance between public, for profit and also the NGO sectors, planning for a cultural heritage asset to be used as a tourist product, including assessing its "robusticity/ability to cope with visitors" (McKercher \& du Cros, 2002, p. 172), must include consideration of the legislative/political context, neighboring assets and regional tourism activity, the socio-historical setting, cultural and economic needs of the host community, physical setting, and accessibility.

The recommendations in this study specifically address the problems of capacity and organizational setup, with a particular view towards equity and encouragement of diversity in both the processes and outcomes of planning. Through these proposals we hope to show one way to instill elements of "formality" within the planning and governance process, which we understand to be includes accountability, inclusive planning, and advocacy for, and production of, pro-poor, community-based heritage tourism development.

In order to coordinate functions performed by various agencies at various scales - conserving WHS monuments, the development of tourism in the (nested) jurisdictions within which these monuments are located, and planning for the land and community of Agra - a reorientation is necessary. Instead of planning for structures or sites of heritage value, agencies should plan for socio-spatial units (that is, communities within places) where heritage is a major resource. We propose a method of merging these three functions into a single planning and management system focusing on governance, spatial innovation, and community involvement. This can have the additional benefits of engaging investors (from major to minor) and community stakeholders in the planning process, and ensuring that long-term funding is accurately estimated and guaranteed.

\section{Governance: reorganization of tourism development}

\section{3rd and 74th Constitutional Amendment Acts}

The 73rd and 74th Constitutional Amendments Acts of 1992 gave urban and rural local governments in India the opportunity to address their financial situation with new powers of taxation. Where used effectively, these powers have allowed local governments to build financial capacity through municipal tools like infrastructure bonds and also to tap into private capital through partnerships. We suggest that, as a first step, Agra Municipal Corporation taps into the opportunities afforded by these Constitutional Amendments to reorganize its financial systems in keeping with international municipal standards, which increasingly are becoming the norm in India. This is particularly important given the national and global significance of 
Agra, and will benefit the local government's institutional capacity for raising funds and executing public works projects.

\section{Jawaharlal Nehru Urban Renewal Mission (JNNURM)}

The JNNURM program was created for the purpose of funding infrastructure projects and encouraging management reform in urban areas in anticipation of their contributing 65\% of the GDP by 2011 (Ministry of Urban Development and Ministry of Urban Employment and Poverty Alleviation, 2006, p. 3). More than US $\$ 20$ billion will be disbursed by 2012 - \$10 billion from the central government and matching grants from state-level or local level authorities (Infrastructure Leasing and Financial Services, 2006a). Agra is one of the cities identified, but JNNURM resources have not been pursued actively by the local authorities.

In 2006, Agra Nagar Nigam (Agra Municipal Corporation, 2006) created a "City Development Plan" with the help of Dutch consultants Allianz Securities Limited, seeking funds for various infrastructure works. Some of these included preservation of heritage buildings and improving streets. According to a newspaper report from March 2008, 16 projects (for water supply, solid waste management and sewage disposal) had been approved in the state of Uttar Pradesh at the time, but work had not begun on any one of them (Indian Express, 2008). According to Mr. Chetan Vaidya, Director of the National Institute of Urban Affairs (NIUA) and a consultant in the establishment of the JNNURM program, it is the lack of implementation of 23 mandatory reforms prescribed under the JNNURM program as well as the 74th and 75th Amendments that are keeping Agra behind other comparable World Heritage-holding sites in India (Khosla, 2009).

\section{Establishment of a central government authority}

We suggest the creation of an overarching governing authority directly under the Central government's Ministry of Tourism. This agency would be responsible for planning and developing the zones described below, along with assuring funding and execution of projects in coordination with community and private sector stakeholders.

In India, there is precedent for such an institutional arrangement. The Delhi Metro Rail Corporation (DMRC), which has successfully implemented an extensive mass transit system in the capital, was established as a Special Purpose Vehicle (SPV). This arrangement was so successful that it is now being replicated in Chennai, Mumbai, and elsewhere. DMRC is also consulting on Jakarta's mass transit project, while students from MBA programs as far away as the USA are making it a case study for efficient management. The core idea of the SPV is that it is an entity formed exclusively for the implementation of a single large-scale infrastructure project. In the case of DMRC, the SPV was formed by the central government and the Delhi state government. Funding sources were clearly earmarked at the beginning of the project, and thus risk was minimized. With an SPV, the new company can deal financially and receive its own credit rating independent of the ups and downs of the "parent" companies. The SPV was also given special powers of planning and execution that overrode the jurisdiction of the Delhi Development Authority and the Municipal Corporations of both Delhi and New Delhi. We propose that tourism in Agra and cities with similar conditions be developed under a similar direct intervention by the central and state governments. 


\section{Spatial innovation: community-based tourism promotion zoning}

Global resources, such as WHSs, sitting in the middle of an unreasonably undeveloped urban context, project an image of inefficiency and institutional failure. The character and community in the quarters around Taj Mahal are part of the experience of the structure. Cultural programming, including seasonal concerts and festivals, could enhance the experience of Agra for tourists. Hence, we propose a network of permanent and impermanent destinations and programming around the theme of the city's cultural heritage surroundings its monuments.

These would be part of a system of Community-Based Tourism-Promotion Zones (CBTPZ, or CTZ for short, at the neighborhood scale) with the WHSs as their focus. The proposed Central Authority, acting directly under the national government, would implement selective capital investments, land use, zoning, building and design regulations, and economic incentives to execute the vision. The proposed zones would allow special land uses, such as mixed-use areas and redevelopment where appropriate. At the outset this idea appears to be akin to that of a Special Economic Zone (SEZ). It is important to note, however, that unlike these, the proposed Community-Based Tourism Promotion Zones are intended for intense community-based commercial use (with emphasis on pro-poor interventions, including light industry). Our proposal draws on and improves on the Taj Expressway idea of creating mixed-use development to in order to draw tourists to Agra and keep them there longer, while at the same time expanding job opportunities for locals. There is precedent for this idea in India: with funding from the JNNURM project, Jaipur's Municipal Corporation is developing a project at Jal Mahal combining conservation of the monument with sustainable tourism and recreational opportunities, including rooftop cafés, boating, tourist cottages and clubs, heritage resorts, villages, a craft market, a floating restaurant, and light and sound shows (Infrastructure Leasing and Financial Services, 2006b).

The first of these CTZ could be sited in the dense part of the city immediately surrounding the Taj, which is already mixed-use, and where people have been living for over 200 years. Visits to this area, known as Taj Ganj, could be integrated with the experience of the Taj Mahal, and visitors could learn about the everyday life of residents alongside their WHS experience. Some of the structures in these areas are interesting historical attractions; a few houses in this district have already been turned into hotels and budget hostels. Other tourist-oriented uses (e.g., restaurants, mini-museums, and craft workshops) could follow. The government could provide incentives for infrastructural and façade improvements, secure tenure, and enhanced training opportunities. A large number of signs in many foreign languages already abound on shop fronts there-Hebrew and Korean are particularly popular. A targeted tourist marketing campaign, including language training for local tourism workers, could further expand such incipient tourist markets. Agra could then go on to invest in other old streets and neighborhoods, such as Sadar Bazar, Raja Mandi, and Fuhara, in order to offer tourists the chance to enjoy not only the WHSs, but also their context - the city and community that is their home.

Greater focus on tourist products is also advisable. Multiple case studies have revealed that "specific soft elements of the urban tourism product are the ones that matter most in determining the attractiveness of a city for international visitors, and yet they are often overlooked by city planners" (Russoa \& van der Borg, 2002, p. 631). These include quality, accessibility, and image projection-overall, a sense of "visitor-friendliness," which serves "to assess whether investments in culture and 
hospitality genuinely respond to the impulses coming from the market" (ibid., p. 631). Cultural heritage assets can be bundled around a theme, creating heritage precincts and tours, organizing festivals, or building heritage centers (Bowen, 2004; McKercher \& du Cros, 2002). All of those arrangements address a need to provide an explanation, a message or story about a heritage asset, through an experience in which tourists feel engaged, and which matches goals of sustainability and equity.

The idea of a spiritual/religious center and museum/park could create a worthy addition to Agra's attractions. The center could be where the relationships among the monuments could be explained and where tourists' appetite for further heritage interpretation could be whetted. Faith and spirituality are also one of the important motivations for tourist visits in India and Uttar Pradesh. An inter-faith religious center could become a centerpiece for showcasing the state's and country's traditions of faith and spirituality, telling a comprehensive story of the evolution of religions in India, with emphasis on the UP region. Such an establishment could offer a spiritual, pluralistic experience not partial to any single faith. It could be complemented by the inclusion of visitor accommodations in the vicinity (including guest rooms in residences within the community), if multi-day seminars, workshops, and retreats are offered.

\section{Community involvement}

Already, a large number of people derive their income and subsistence directly or indirectly from industries related to the WHSs in Agra. This includes traditional industries such as leather, marble inlaying, carpets, and jewelry, which are heavily dependent on tourists for their sales. Further, a common occupation for Agra's youth is guiding tours. The government issues licenses for guides (but these are easily manufactured illegally too). Other businesses, such as motels, transportation, restaurants and similar services also depend on the tourist economy. The businesses and residents of Taj Ganj should be part of the planning process from the start. In addition, there are also other (relatively smaller and low-income) communities ripe for holistic integration in the tourism industry. Civil society groups have been working with these communities - for example, the Tourism Guild of Agra, a conglomeration of major players in the tourism industry who have organized themselves as an interest group, and the Center for Urban and Regional Excellence (CURE), an NGO involved with creating opportunities for the poor in the tourism sector.

One of the best examples of local initiatives to benefit the community is the Crosscutting Agra Project (CAP), initiated by the Center for Urban and Regional Excellence (CURE) in 2005, and assisted by the private sector (particularly the Tourism Guild of Agra) and USAID's Indo-US Financial Institutions Reform and Expansion Project (Indo-US FIRE-D project). This urban innovation is aimed at "leveraging Agra's lesser-known heritage sites for improving sanitation and livelihood in low-income communities" (Indo-US FIRE-D Project, 2007, p.1). The project area was close to the Taj Mahal, other heritage sites, and the low-income community of Kucchpura. A one-kilometer loop identified as a "Heritage Walk," linked several low-income communities (about 2,000 households) with "lesserknown monuments" and architectural features. Micro-enterprises were set up for women, and some young men from the communities were trained to help tourists on the Heritage Walk. The communities were also mobilized to undertake waste 
disposal schemes, and community and individual toilets were constructed. Ms. Renu Khosla, the Director of CURE, underlined the need to plan for and utilize all heritage sites in Agra, and not only the WHSs (Khosla, 2009).

We support the CAP idea and recommend that the Authority under the Central government work on these kinds of community-based partnerships, with specific attention to Promotion Zones. Through this framework we expect that the lesserknown monuments and intangible assets of Agra, such as its folk tales and traditions and the history associated with the city, as well as expressions of contemporary local culture in clothing, cuisine, craftsmanship, dance, and everyday life in the bazaars and on the banks of the river Yamuna, can be brought into tourists' experience of Agra and leveraged for the benefit of the local community members, with particular attention to the poorest among them.

\section{Revisiting UNESCO's role}

We offer three suggestions regarding UNESCO's potential impact on cities that are host to World Heritage Sites. In the context of developing countries with limited resources, what responsibility could be taken by UNESCO in ensuring that WHS monuments benefit the communities in which they are located? In relatively small cities, especially those of such paramount importance as Agra, UNESCO could contribute more than the WHS designation. Firstly, the procedures for World Heritage designation and the monitoring of WHSs could be more forceful in demanding and evaluating explicit plans, benchmarks, time-frames, and financial commitments for the promotion of pro-poor, community-based heritage tourism development around WHSs.

The second contribution that UNESCO could make is assisting in raising funds from other sources and channeling financial resources towards the development of WHS-hosting cities. This is not simply a demand for more funds, but rather for recognition of the need to support host cities, not just the heritage properties. In the case of Agra, a UNESCO report shows two UN contributions: \$17,865 to address pollution issues and \$20,788 to be shared between the site of Konarak temples and Taj Mahal for "technical cooperation" (UNESCO, 2002). Additionally, according to a UNESCO report, a French private enterprise committed \$236,735 for a three-year research project on conservation of the Taj. Another UNESCO report shows "extrabudgetary funds mobilized by the UNESCO Division of Cultural Heritage from 1998-2003 total[ing] \$158,200 for research and conservation training." The benefactor in this case is named as Foundation Rhône-Poulenc. We suggest that UNESCO, in collaboration and coordination with UNDP and UN-Habitat, also assist in developing plans to assist in for tourism-related projects and in managing the urban context of the WHSs. Agra needs these plans and funds to break the cycle of inadequate infrastructure development leading to poor performance in the tourism sector, which in turn would serve UNESCO's stated goals.

Thirdly, UNESCO could provide institutional support in terms of capacitybuilding. We suggest a deeper commitment in organizing (or encouraging and demanding) training workshops for local professionals, getting urban planning and business schools involved in the process. In general UNESCO should enlarge its focus from designation of World Heritage Sites to helping heritage communities develop thoroughly sustainable preservation and development practices-which again would serve its stated goals. 


\section{Discussion}

There is no doubt that Agra's three WHSs distinguish it as a city of world significance. However, existing conditions with respect to infrastructure provision, the quality of the tourist experience, and community benefits being drawn from heritage sites are woefully disproportionate to their potential. The Agra case reveals a developmental paradox, whereby advances new opportunities in the tourist industry created by World Heritage designation do not lead to proportionate advances in local community development, and can actually exacerbate local developmental challenges and socio-spatial inequalities.

Problems in the tourism sector reflect deep institutional weaknesses that affect other aspects of development too. "Heritage tourism raises more than planning and management issues for developing countries; they are fundamentally the problems of development" (Nuryanti, 1996, p. 249). In the context of this study, Ananya Roy's (2009) criticisms of planning in India are particularly relevant. According to Roy, the problems of urban governance in India originate from the "idiom" of informality. Roy argues that this informality is embedded within planning practices and institutionalized through the writing (open-ended and susceptible to misuse) and selective implementation of plans, which creates an "axis of inequality" in Indian cities. Further, Roy criticizes the State itself as an "informalized entity" (p. 81). Roy's analysis of the lack of order in the planning process is pertinent to this discussion. What we see in Agra is a similar phenomenon, where many "arbitrary and fickle practices" can be held responsible for failures of planning. We have discussed many of these in foregoing sections of this paper.

What Roy critiques as "informality" is in our opinion a restatement of the problems of unequal power relations in processes of planning and development. As such, these problems are present in all planning cultures to some extent. What we have found in Agra in terms of the looseness of institutional roles and successive uncoordinated planning exercises may be understood in terms of informality; yet Roy's critique leaves little room for planners and communities to move forward. We believe that "informality" of this kind can be addressed within the planning process. Partially overcoming the shortcomings that this informality produces is possible by changing governance and planning practices (Irazábal, 2005).

The problem (certainly in the case of Agra, and in urban India in general) lies in political manipulation (leading to flawed visioning), lack of capacity of local agencies, and an unclear mandate fragmented among numerous agencies. Drawing on successful ideas (e.g., SPVs for infrastructure development, community-based projects etc.) we have tried to show that, given the presence of political will and community support, informality in governance restructuring can give way to focused action.

Following Irazábal (2009), the emancipatory promise of planning - in Agra or elsewhere - can be realized to the extent that opportunities for the creation and nurturing of network power, liberating knowledge, empowering subjectivities, and spaces of solidarity are expanded. In Agra, the promotion of pro-poor, communitybased heritage tourism development would be critically instrumental in redressing the current developmental paradox. The specific recommendations offered here can assist in setting a basic platform for the unleashing of the impressive communitydevelopment potential and emancipatory promise of planning laying dormant around Agra's WHSs and other assets.

We have not included in the scope of this paper strategies to combat corruption, party politics (including strained center-state relations when different political parties 
are in power), or resistance by the central government towards decentralization and devolution. It is critical, however, that these issues are addressed through fair political accountability, power-devolution, and profit-sharing arrangements. Our proposal, nonetheless, does provide the outline for a change in governance structure in conjunction with spatial planning and community participation, so that heritage sites and the city where they are located may benefit each other.

The paradoxes and potential of economic, tourism, and community development in Agra echo in other developing localities with World Heritage sites around the world (Irazábal, 2009b; Irazábal \& Morán, 2008). Rooted in an assessment of the problems and challenges of each locality, the lessons of pro-poor, community-based heritage tourism development can offer the hope of turning white elephants into golden geese.

\section{References}

Agra Municipal Corporation. (2006). Agra City Development Plan. Agra: AMC

Ashley, C., \& Roe, D. (2001). Making tourism work for the poor: Strategies and challenges in Southern Africa. Development Southern Africa, 19, 61-82.

Ashworth, G. (2006). Book Review (The Politics of World Heritage: Negotiating Tourism and Conservation, Edited by David Harrison and Michael Hitchcock. Channel View Publications, 2005). Annals of Tourism Research, Vol. 33, No. 1, pp. 273-275, 2006.

ASI. (2011). Activities. Retrieved March 20, 2008, from http://asi.nic.in/asi_aboutus_ activities.asp

Bowen, Heather. Book Review (Cultural tourism: the partnership between tourism and cultural heritage management. Bob McKercher and Hilary du Cross; The Haworth Hospitality Press, Binghamton, New York, 2002) Tourism Management 25 (2004) 409-416.

Brohman, J. (1996). New directions in tourism for third world development. Annals of Tourism Research, 23(1), 48-70.

Department of Tourism, Government of India. (2002). Final report on 20 years perspective plans for Uttar Pradesh, November, 2002. Prepared by A.F. Ferguson and Co. Delhi. Retrieved March 20, 2008, from http://tourism.gov.in/pplan/up.pdf

Drost, A. (1996). Research notes: Developing sustainable tourism for world heritage sites. Annals of Tourism Research, 23(2), 479-492.

Edensor, T. (1998). Tourists at the Taj: Performance and meaning at a symbolic site. Routledge: London.

Hall, C.M. (Ed.) (2007). Pro-poor tourism - who benefits? Perspectives on tourism and poverty reduction. Current Themes in Tourism. Clevedon: Channel View Publications.

Harrison, D., \& Hitchcock, M. (2005). (Eds.) Politics of world heritage: Negotiating tourism and conservation. Channel View Publications: Clevedon.

Harrison, D., \& Schipani, S. (2007). Lao tourism and poverty alleviation: Commounity-based tourism and the private sector. In C.M. Hall (Ed.), Pro-poor tourism - who benefits? Perspectives on tourism and poverty reduction, Current Themes in Tourism (84-117). Clevedon: Channel View Publications.

Indian Express. (2008). Lack of coordination continues to haunt JNNURM in the state. Retrieved March 20, 2008, from http://www.expressindia.com/latest-news/lack-of-coordinationcontinues-to-haunt-jnnurm-in-the-state/285067/

Indo-US Financial Institutions Reform and Expansion Project (2007). Project Note no. 37: Leveraging Agra's Lesser-known Heritage Sites for Improving Sanitation and Livelihood in Low-income Communities Crosscutting Agra Project (CAP), Uttar Pradesh, India. New Delhi: Indo-US FIRE(D).

Infrastructure Leasing and Financial Services (2006a). IL\&FS IDC Services offered for JNNURM and UIDSSMT Schemes. Accessed on November 14, 2009 from http:// www.ilfsindia.com/downloads/bus_concept/JNNURM.pdf

Infrastructure Leasing and Financial Services (2006b). Projects: Jal Mahal, Jaipur. Accessed on November 14, 2009 from http://www.ilfsindia.com/projects1.asp?Category=1\& Project $=8 \&$ subLink $=16$ 
Irazábal, C. (2005). City making and urban governance in the Americas: Curitiba and Portland. Aldershot: Ashgate.

Irazábal, C. (2009a). Realizing planning's emancipatory promise: Learning from regime theory to strengthen communicative action. Planning Theory, 8(2), 115-139.

Irazábal, C. (2009b). (Un)Planning Costa Rican coastal development: Tourism and the Nature-City Paradox in Jacó. Paper presented at the Association of Collegiate Schools of Planning Conference, "Reinvesting in America: The New Metropolitan Planning Agenda", October 1-4, Crystal City, Virginia.

Irazábal, C., \& Morán, O. (2008). Planning implications of tourism development: The Mexican Pacific Riviera. Paper presented at the Joint Association of European Schools of Planning (AESOP) and Association of Collegiate Schools of Planning (ACSP) Conference, July 6-11, Chicago.

Kakwani, N., \& Pernia, E.M. (2000). What is pro-poor growth? Asian Development Review, $18(1), 1-16$.

Khosla, R. (2009). Personal Interview, 2 January.

Leask, A., \& Fyall, A. (Eds.). (2006). Managing world heritage sites. Oxford: ButterworthHeinemann.

McKercher, B., \& du Cross, H. (2002). Cultural tourism: The partnership between tourism and cultural heritage management. Binghampton, New York: The Haworth Hospitality Press.

Ministry of Urban Development and Ministry of Urban Employment and Poverty Alleviation. (2006). Jawaharlal Nehru National Urban Renewal Mission: Overview. Retrieved 20 March, 2008, from http://jnnurm.nic.in/nurmudweb/toolkit/Overview.pdf

NIUA. (2001). City profile, Agra. Retrieved March 20, 2008, from http://www.niua.org/ city des.asp?title=Agra

Nuryanti, W. (1996). Heritage and postmodern tourism. Annals of Tourism Research, 23(2), 249-260.

Roy, A. (2009). Why India cannot plan its cities: Informality, insurgence and the idiom of urbanization. Planning Theory, 8(1), 76-87.

Russoa, A.P., \& van der Borg, J. (2002). Planning considerations for cultural tourism: A case study of four European cities. Tourism Management, 23, 631-637.

Ryan, C. (2002). Equity, management, power sharing and sustainability issues of the 'new tourism. Tourism Management, 23, 17-26.

Schyvens, R. Exploring the tourism-poverty nexus. In C.M. Hall (Ed.), Pro-poor tourism - who benefits? Perspectives on tourism and poverty reduction. Current Themes in Tourism (127141). Clevedon: Channel View Publications.

Shanks, C. (2009). The global compact: The conservative politics of international tourism. Futures, 41(6), 360-366.

Shetawy, A.A.A., \& El Khateeb, S.M. (2009). The pyramids plateau: A dream searching for survival. Tourism Management, 30(6), 819-827.

UNESCO (2002). State of conservation of the World Heritage Properties in the Asia-Pacific Region. Retrieved January 10, 2009, from http://whc.unesco.org/archive/periodic reporting/apa/cycle01/section2/252-summary.pdf

Vaidya, C. (2008). Personal interview, 31 December.

Wager, J. (1995). Developing strategy for the Angkor World Heritage Site. Tourism Management, 16(7), 515-523.

Wager, J. Developing a strategy for the Angkor World Heritage Site. Tourism Management, 16(7), 515-523. 